Article

\title{
Two Hydrothermal Events at the Shuiyindong Carlin-Type Gold Deposit in Southwestern China: Insight from Sm-Nd Dating of Fluorite and Calcite
}

\author{
Qinping Tan ${ }^{1, *}$, , Yong Xia ${ }^{1, *}$, Zhuojun Xie ${ }^{1}$, Zepeng Wang ${ }^{2}$, Dongtian Wei ${ }^{3}$, Yimeng Zhao ${ }^{1,4}$, \\ Jun Yan ${ }^{1,2,5}$ and Songtao $\mathrm{Li}^{1,2,3}$ \\ 1 State Key Laboratory of Ore Deposit Geochemistry, Institute of Geochemistry, Chinese Academy of Sciences, \\ Guiyang 550081, China; xiezhuojun@vip.gyig.ac.cn (Z.X.); zhaoyimeng@mail.gyig.ac.cn (Y.Z.); \\ xiao127721@sina.com (J.Y.); lisongtaozgh@163.com (S.L.) \\ 2 No.105 Geological Team, Guizhou Bureau of Geology and Mineral Exploration \& Development, \\ Guiyang 550018, China; wangzepengyu@126.com \\ 3 Guangxi Key Laboratory of Exploration for Hidden Metallic Ore Deposits, College of Earth Sciences, \\ Guilin University of Technology, Guilin 541006, China; weidongtian2016@163.com \\ 4 University of Chinese Academy of Sciences, Beijing 100039, China \\ 5 College of Resources and Environmental Engineering, Guizhou Institute of Technology, \\ Guiyang 550003, China \\ * Correspondence: tanqinping@vip.gyig.ac.cn (Q.T.); xiayong@vip.gyig.ac.cn (Y.X.)
}

Received: 8 March 2019; Accepted: 4 April 2019; Published: 12 April 2019

check for updates

\begin{abstract}
The Shuiyindong Gold Mine hosts one of the largest and highest-grade, strata-bound Carlin-type gold deposits discovered to date in Southwestern China. The outcrop stratigraphy and drill core data of the deposit reveal Middle-Upper Permian and Lower Triassic formations. The ore is mainly hosted in Upper Permian bioclastic limestone near the axis of an anticline. The gold is mainly hosted in arsenian pyrite and arsenopyrite, mainly existing in the form of crystal lattice gold, submicroscopic particles and nanoparticles. Fluorite commonly occurs at the vicinity of an unconformity between the Middle-Upper Permian formations, which is proposed to be the structural conduit that fed the ore fluids. Calcite commonly fills fractures at the periphery of decarbonated rocks, which contain high grade orebodies. This study aimed to verify the occurrence of two distinct hydrothermal events at the Shuiyindong, based on $\mathrm{Sm}-\mathrm{Nd}$ isotope dating of the fluorite and calcite. For this purpose, rare-earth element (REE) concentrations, $\mathrm{Sm} / \mathrm{Nd}$ isotope ratios, and Sm-Nd isochron ages of the fluorite and calcite were determined. The fluorite and calcite contain relatively high total concentrations of REE (12.3-25.6 $\mu \mathrm{g} / \mathrm{g}$ and 5.71-31.7 $\mu \mathrm{g} / \mathrm{g}$, respectively), exhibit variable Sm/Nd ratios (0.52-1.03 and 0.57-1.71, respectively), and yield Sm-Nd isochron ages of 200.1 \pm 8.6 Ma and $150.2 \pm 2.2 \mathrm{Ma}$, with slightly different initial $\varepsilon_{\mathrm{Nd}}(\mathrm{t})$ values of -4.4 and -1.1 , respectively. These two groups of $\mathrm{Sm}-\mathrm{Nd}$ isochron ages suggest two episodes of hydrothermal events at the Shuiyindong gold deposit. The age of the calcite probably represents the late stage of the gold mineralization period. The initial $\varepsilon_{\mathrm{Nd}}(\mathrm{t})$ values of the fluorite and calcite indicate that the $\mathrm{Nd}$ was probably derived from mixtures of basaltic volcanic tuff and bioclastic limestone from the Permian formations.
\end{abstract}

Keywords: Sm-Nd dating; Shuiyindong; Carlin-type gold deposit; Southwestern China

\section{Introduction}

The Dian-Qian-Gui "Golden Triangle", located at the junction of Yunnan, Guizhou, and Guangxi Provinces in Southwestern China (Figure 1), is famous for hosting clusters of Carlin-type gold deposits [1-4]. More than 200 Carlin-type gold deposits and occurrences have been identified in the 
"Golden Triangle", with a total proven gold reserve of more than 800 tons [3,5]. It is the second-largest Carlin-type gold mineralized area in the world, after the largest in Nevada, USA [3,5].

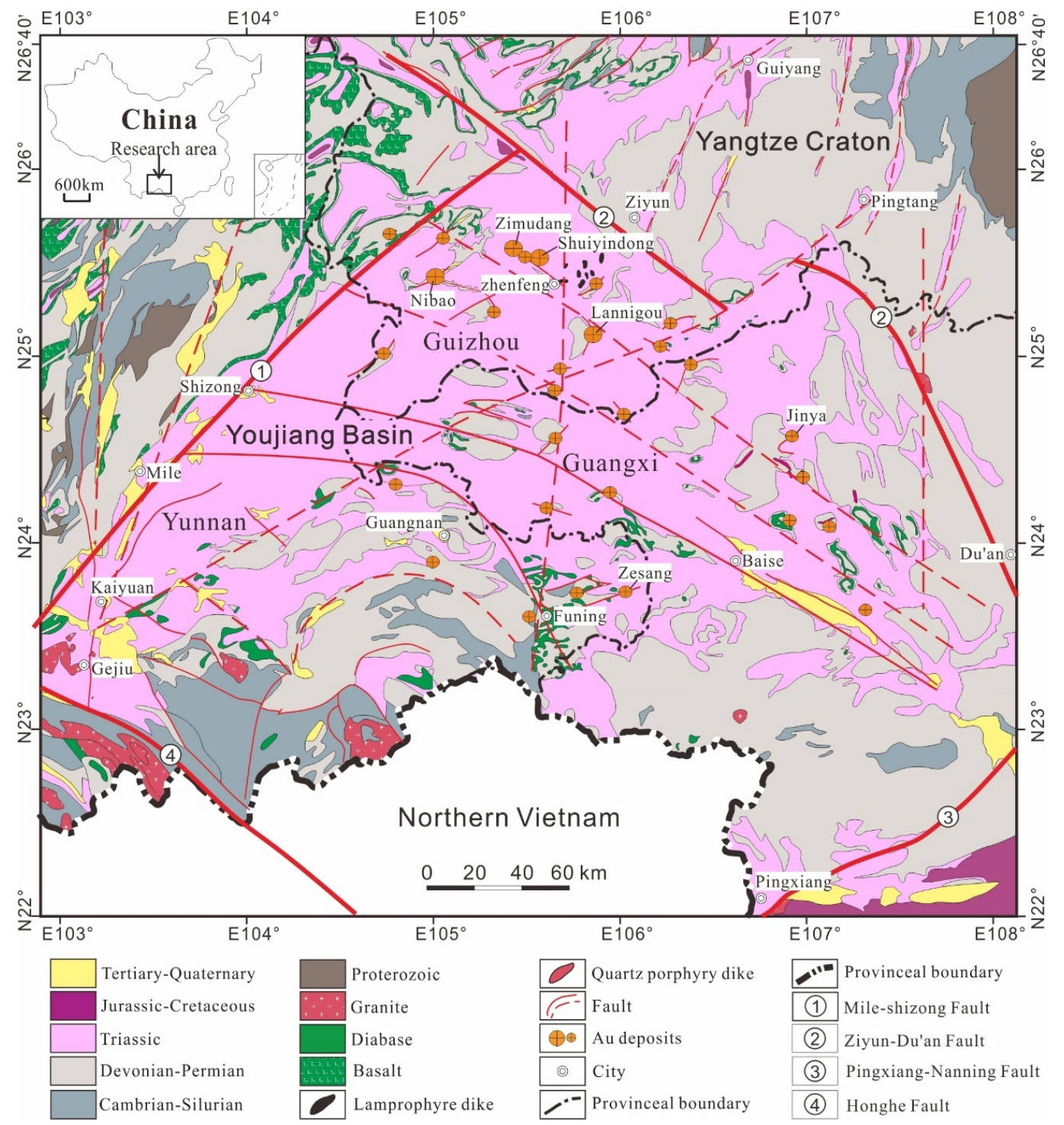

Figure 1. Geologic map of the Dian-Qian-Gui "Golden Triangle" region in Southwestern China (modified after Su et al. [5] and 1:2,500,000 Chinese geological map [6]).

Direct dating of hydrothermal deposits is critical for properly evaluating their relationships to tectonic, magmatic, and metamorphic events. However, despite previous detailed investigations, the ages of Carlin-type gold deposits in Southwestern China are poorly constrained. Chen et al. [7] obtained a ${ }^{40} \mathrm{Ar}-{ }^{39} \mathrm{Ar}$ plateau age of $194.6 \pm 2 \mathrm{Ma}$, using sericite in quartz veins from the Lannigou gold deposit. Chen et al. [8] reported ages of $204 \pm 19 \mathrm{Ma}, 206 \pm 22 \mathrm{Ma}$, and $235 \pm 33 \mathrm{Ma}$ based on Re-Os isotopes of arsenopyrite from the Lannigou, Jinya, and Shuiyindong deposits, respectively. Pi et al. [9] dated hydrothermal rutile and sericite from the Zhesang gold deposit and obtained an in situ U-Pb isochron age of $213.6 \pm 4.6 \mathrm{Ma}$ for rutile and a ${ }^{40} \mathrm{Ar}-{ }^{39} \mathrm{Ar}$ plateau age of $215.3 \pm 1.9 \mathrm{Ma}$ for sericite. In addition, Sm-Nd isochron ages of $134 \pm 3 \mathrm{Ma}$ and $136 \pm 3$ Ma have been reported for calcite from the Shuiyindong gold deposit [10]. Wang [11] reported another Sm-Nd isochron age of $148.4 \pm 4.8 \mathrm{Ma}$ of calcite from the Zimudang gold deposit. Chen et al. [12] obtained weighted-mean secondary ion mass spectrometry (SIMS) Th- $\mathrm{Pb}$ age of $141 \pm 3 \mathrm{Ma}$ for apatite from the Nibao gold deposit. These ages can be mainly classified into two groups-ca. 130-150 Ma and 200-230 Ma. Nevertheless, further 
research is required on whether there were two episodes of hydrothermal or metallogenesis events during the formation of the Carlin-type gold deposits in the Dian-Qian-Gui "Golden Triangle" area in Southwestern China.

$\mathrm{Sm}$ and $\mathrm{Nd}$ have similar chemical characteristics. Therefore, the daughter ${ }^{143} \mathrm{Nd}$ decayed from the parent ${ }^{147} \mathrm{Sm}$ is often preserved in the mineral lattice, i.e., the $\mathrm{Sm}-\mathrm{Nd}$ isotope system has high likelihood of being closed and capable of resisting weathering and alteration to some degree [13]. Therefore, $\mathrm{Sm}-\mathrm{Nd}$ isotope dating is an effective method for precisely determining the time of hydrothermal events [14-16], even for relatively young mineralization [17]. It has been successfully used for dating hydrothermal Ca-bearing minerals, such as calcite [18-20], scheelite [15,21,22], fluorite [23-25], and tourmaline $[15,21]$.

The ideal method for determining the age of gold deposits is to analyze minerals that are known to have formed coevally with the gold. Fluorite and calcite are common gangue minerals in Carlin-type gold deposits in Southwestern China. Previous research indicated that the rare-earth element (REE) patterns of fluorite and calcite are unique, characterized by middle rare-earth element (MREE) enrichment and relatively variable $\mathrm{Sm} / \mathrm{Nd}$ ratios [10,26], which is favorable for $\mathrm{Sm}-\mathrm{Nd}$ isotope dating. The Shuiyindong gold deposit is the largest gold deposit reported thus far in Southwestern China, with a total gold reserve of over 260 tons [27,28]. In this study, we selected the Shuiyindong gold deposit as a case study, and explore whether there were two distinct hydrothermal events based on $\mathrm{Sm}-\mathrm{Nd}$ isotope dating of fluorite and calcite.

\section{Geological Setting}

Carlin-type gold deposits in the Dian-Qian-Gui area are restricted to the Youjiang Basin (Figure 1). The basin is bound to the northwest and northeast by the Mile-Shizong fault and Ziyun-Du'an fault, respectively, separating the basin from the Yangtze Craton $[5,8]$. The southwestern and southeastern margins of the basin are separated from the Simao and Cathaysia blocks by the Honghe and Pingxiang-Nanning faults, respectively $[8,29]$.

The Shuiyindong deposit, located in the northern part of the Youjiang Basin, lies approximately $20 \mathrm{~km}$ northwest of Zhenfeng in Guizhou Province (Figure 1). The mining area has been divided into four ore blocks, Shuiyindong, Xionghuangyan, Bojitian, and Nayang (Figure 2). Detailed geological descriptions of the deposit are available in Su et al. [30] and Tan et al. [28,31].

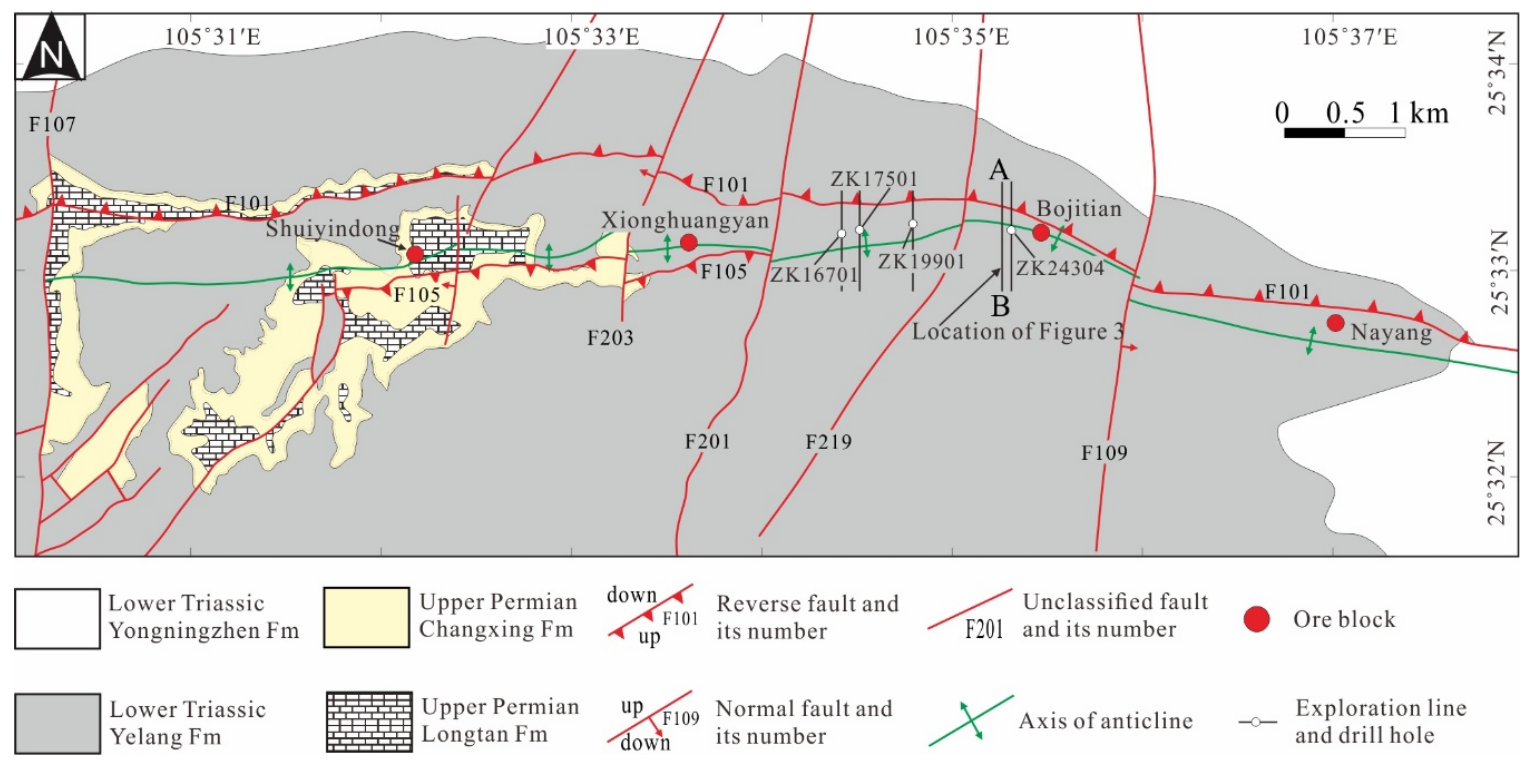

Figure 2. Geological map of the Shuiyindong gold deposit. The Shuiyindong mining area has been divided into four ore blocks: Shuiyindong, Xionghuangyan, Bojitian, and Nayang. 
The outcrop stratigraphy and drill core data in the Shuiyindong mining area reveal Permian and Triassic formations that consist of muddy limestone, bioclastic limestone, siltstone, and argillite (Figures 2 and 3). The Middle Permian Maokou formation, a massive bioclastic limestone, is conformably overlain by the Upper Permian Longtan, Changxing, and Dalong and Lower Triassic Yelang formations (Figure 3). These strata were deformed into a nearly east-west-trending anticline with north and south limbs cut by reverse faults F101 and F105, respectively (Figure 2; [32]). The Maokou and Longtan formations are separated by an unconformity (SBT), consisting of silicified, brecciated argillite and limestone. SBT has been proposed as the structural conduit that fed ore fluids into the anticline core [28].

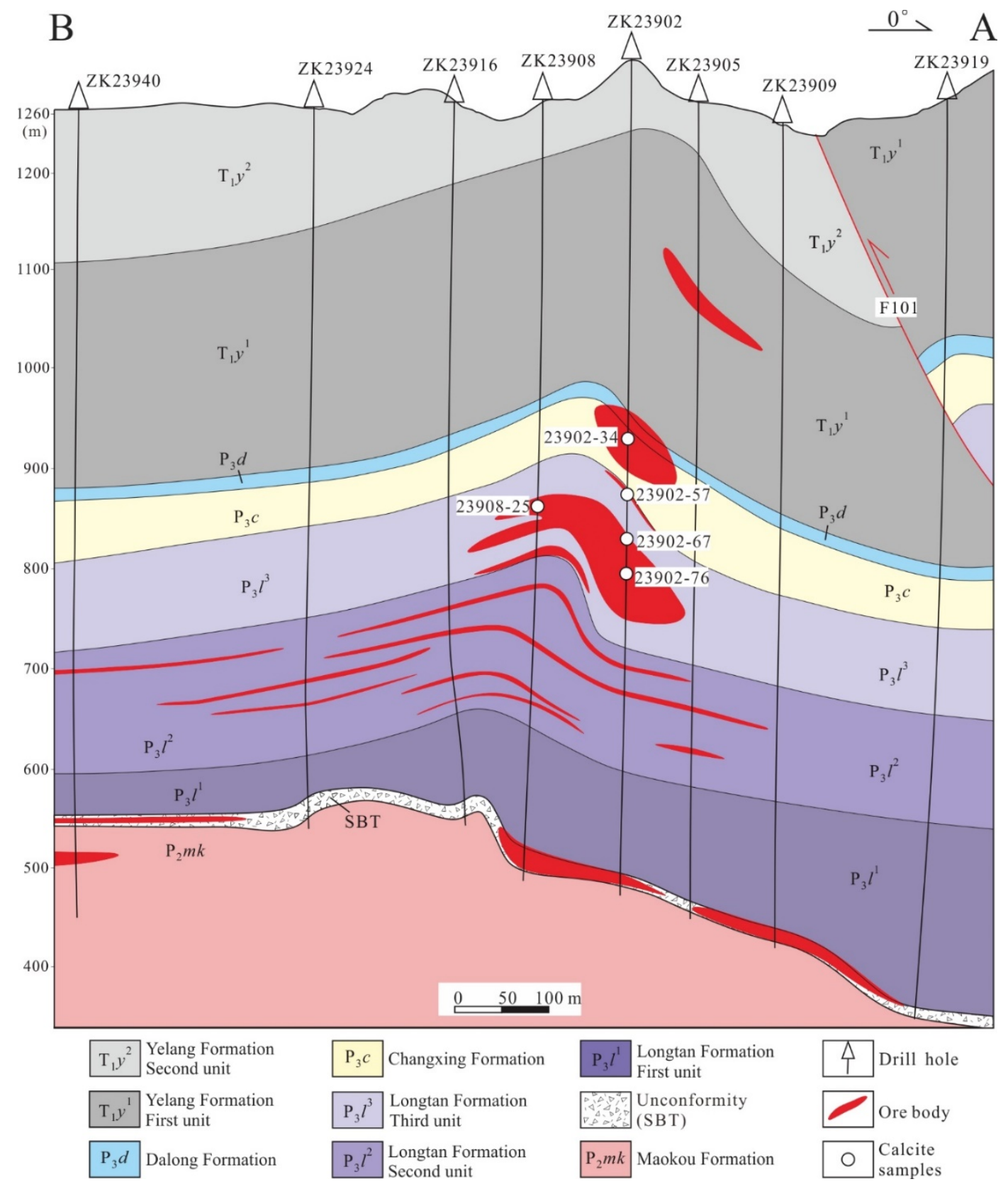

Figure 3. Geological cross section A-B through the Shuiyindong mining area (looking west) showing its major structures and stratigraphic units.

In this deposit, gold mineralization occurs mainly at the vicinity of the anticlinal core, and is preferentially disseminated in bioclastic limestone and calcareous siltstone of the Longtan formation at 
depths of 100-1400 m below the surface (Figure 3). In addition, SBT hosts low-grade orebodies (Figure 3). The mineralization is closely associated with decarbonatization (carbonate dissolution), silicification, sulfidation, and dolomitization, similar to Carlin-type gold deposits in Nevada, USA [33]. The gold is mainly hosted in arsenian pyrite and arsenopyrite as invisible forms including submicroscopic particles, nanoparticles, and crystal lattice gold, which suggests that sulfidation took place during the main mineralization stage [34]. Sulfides formed from sulfidation consist mainly of arsenian pyrite, arsenopyrite, marcasite, and lesser orpiment, realgar (Figure 4a,b), and stibnite. Gangue minerals consist of quartz, dolomite, calcite (Figure $4 \mathrm{a}, \mathrm{b}$ ), fluorite (Figure 4c,d), and clay minerals (e.g., kaolinite and illite). Fluorite generally occurs at the vicinity of SBT, and calcite commonly fills fractures at the periphery of highly porous decarbonated rocks that host high-grade orebodies.
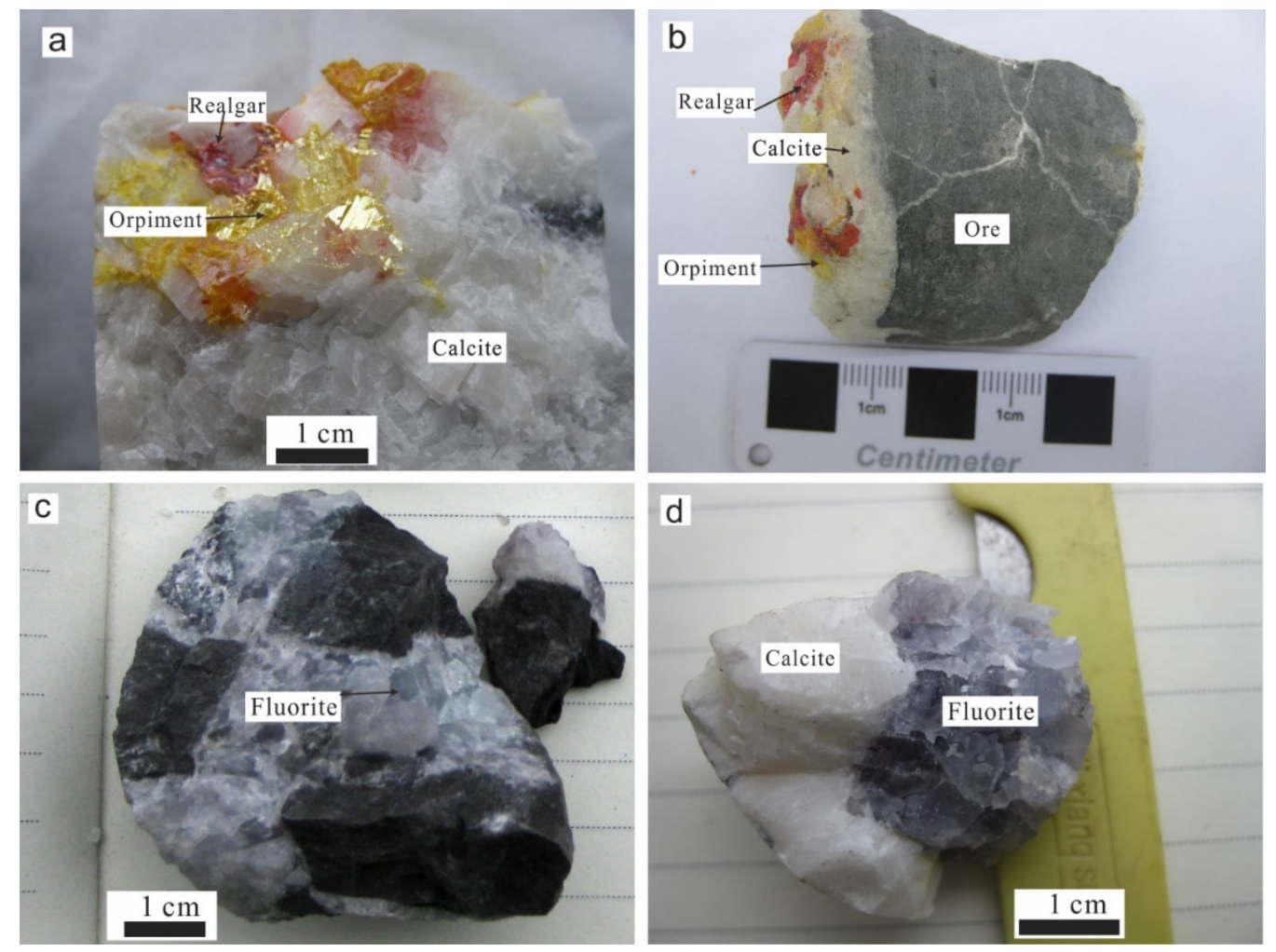

Figure 4. Photographs of calcite and fluorite samples from Shuiyindong. (a,b) Calcite samples containing intergrown realgar and orpiment from drill cores at the periphery of decarbonated rocks; (c,d) fluorite samples cementing argillite breccia or intergrowth with calcite at the vicinity of SBT.

\section{Sampling and Analytical Methods}

Six fluorite samples were collected from drill holes ZK16701, ZK17501, ZK19901, and ZK24304 of SBT at depths of 600-747 m below the surface (Figure 2). Five calcite samples, containing intergrown realgar and orpiment, were collected from drill holes ZK23908 and ZK23902 at depths of 376-522 m below the surface (Figure 3). Pure fluorite and calcite separates were hand-picked under a binocular microscope and crushed to 200 mesh in an agate mortar.

Prior to isotopic analysis, concentrations of REE in subsamples from the separated fluorite and calcite were determined by a Perkin-Elmer Sciex ELAN 6000 inductively coupled plasma quadrupole mass spectrometer at the Institute of Geochemistry at the Chinese Academy of Sciences. Sm and Nd concentrations and isotope ratio measurements were performed using a MAT-261 thermal ionization mass spectrometer at the Tianjin Institute of Geology and Mineral Resources at the Chinese Academy of Geological Sciences. Detailed analytical procedures are available in Peng et al. [13], Su et al. [10], and Zhang et al. [35]. Nd ratios were normalized to a ${ }^{146} \mathrm{Nd} /{ }^{144} \mathrm{Nd}$ ratio of 0.7219 , using a power 
law fractionation correction. The reproducibility of isotopic ratios is better than $0.005 \%(2 \sigma)$; the precision for $\mathrm{Sm}$ and $\mathrm{Nd}$ concentrations is less than $0.5 \%$ of the quoted values $(2 \sigma)$. The average element concentrations and isotopic ratios of the standard BCR-1 determined during this study were $6.57 \mu \mathrm{g} / \mathrm{g}$ for Sm, $28.75 \mu \mathrm{g} / \mathrm{g}$ for $\mathrm{Nd}$, and $0.512644 \pm 0.000005(2 \sigma, n=6)$ for ${ }^{143} \mathrm{Nd} /{ }^{144} \mathrm{Nd}$, which are consistent with the values of $6.58 \mu \mathrm{g} / \mathrm{g}$ for Sm and $28.8 \mu \mathrm{g} / \mathrm{g}$ for $\mathrm{Nd}$ in the literature [22]. Replicate analyses of the Johnson and Mattey ${ }^{\circledR} \mathrm{Nd}$ standard (JMC) provided an average ${ }^{143} \mathrm{Nd} /{ }^{144} \mathrm{Nd}$ ratio of $0.511132 \pm 0.000005(2 \sigma, n=6)$. Average blanks were $0.03 \mathrm{ng}$ for Sm and $0.05 \mathrm{ng}$ for $\mathrm{Nd}$. The decay constant of $\lambda^{147} \mathrm{Sm}=6.54 \times 10^{-12} /$ year was used in the age calculation. Sm-Nd isochron ages were calculated using the computer program ISOPLOT 2.9 [36].

\section{Results}

REE concentrations and Sm-Nd isotopic compositions of fluorite and calcite are shown in Figure 5 and listed in Tables 1 and 2, respectively. All the samples contained considerable $\Sigma$ REE concentrations (12.3-25.6 $\mu \mathrm{g} / \mathrm{g}$ for fluorites and 5.71-31.7 $\mu \mathrm{g} / \mathrm{g}$ for calcites) and variable $\mathrm{Sm} / \mathrm{Nd}$ ratios $(0.52-1.03$ for fluorites and 0.57-1.71 for calcites). Chondrite-normalized REE patterns of fluorite and calcite all showed MREE enrichment characteristics (Figure $5 a, b$ ). However, fluorite and calcite exhibited certain apparent differences between their REE patterns. Fluorite was characterized by negative Eu anomalies $(\delta \mathrm{Eu}=0.67-0.78$; Table 1$)$ and a parabolic shape, with the peak between Gd and Ho (Figure 5a), whereas calcite was characterized by positive Eu anomalies $(\delta \mathrm{Eu}=1.01-1.54$; Table 1$)$ and a hump shape with the peak on Eu (Figure 5b).
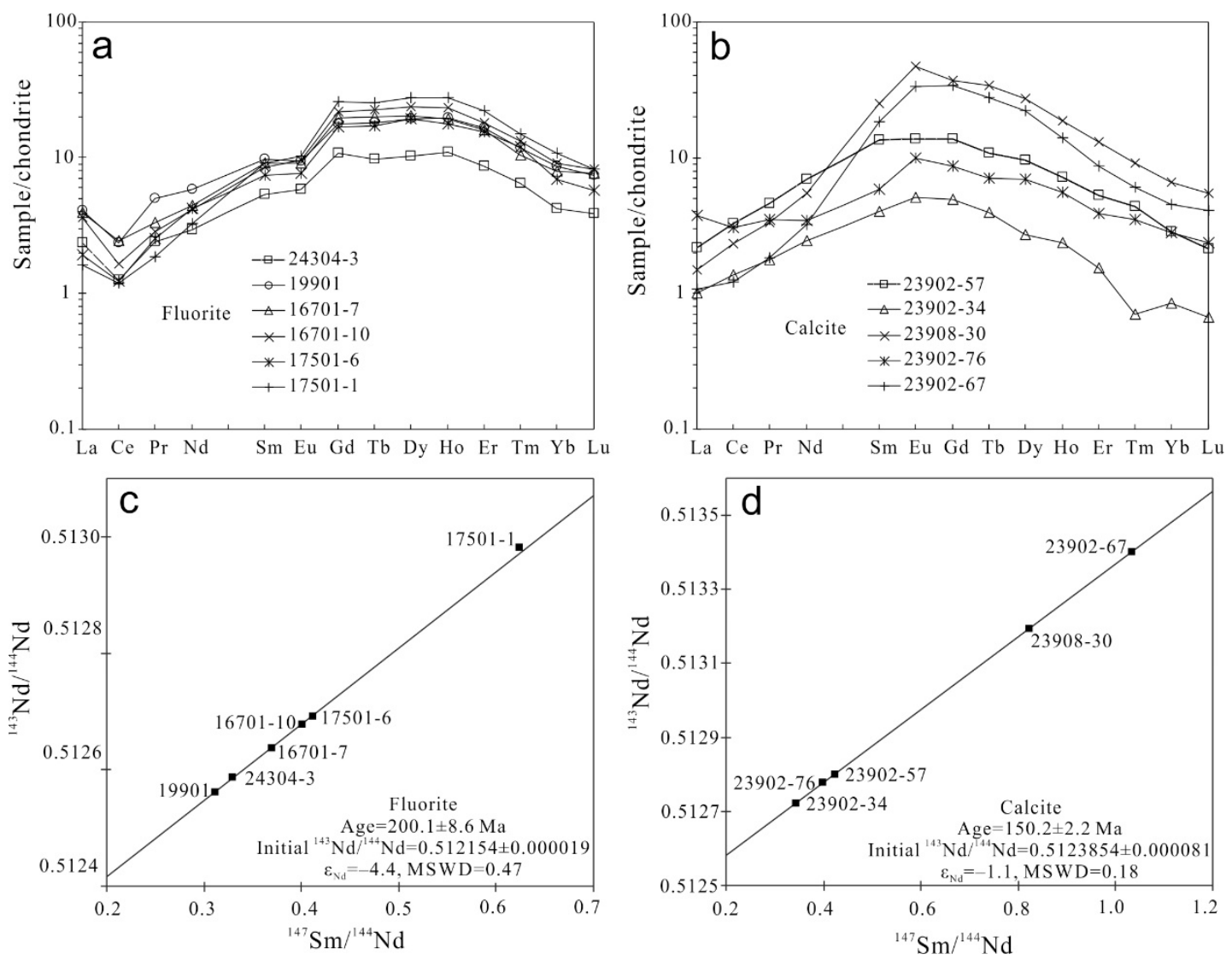

Figure 5. Chondrite-normalized REE patterns $(\mathbf{a}, \mathbf{b})$ and corresponding $\mathrm{Sm}-\mathrm{Nd}$ isochron ages (c,d) for fluorite and calcite from the Shuiyindong deposit. 
Table 1. REE data $(\mu \mathrm{g} / \mathrm{g})$ for fluorite and calcite from the Shuiyindong deposit.

\begin{tabular}{|c|c|c|c|c|c|c|c|c|c|c|c|c|c|c|c|c|c|c|}
\hline Sample Number & Minerals & Locality & La & $\mathrm{Ce}$ & $\operatorname{Pr}$ & $\mathrm{Nd}$ & Sm & Eu & Gd & $\mathbf{T b}$ & Dy & Ho & Er & $\mathrm{Tm}$ & $\mathrm{Yb}$ & Lu & $\Sigma \mathrm{REE}$ & $\delta \mathrm{Eu}$ \\
\hline $16701-7$ & Fluorite & ZK16701, $615 \mathrm{~m}$ & 0.938 & 1.48 & 0.317 & 2.06 & 1.40 & 0.523 & 4.02 & 0.745 & 5.17 & 1.10 & 2.64 & 0.266 & 1.34 & 0.196 & 22.2 & 0.67 \\
\hline $16701-10$ & Fluorite & ZK16701, 627 m & 0.850 & 0.999 & 0.269 & 1.94 & 1.29 & 0.552 & 4.43 & 0.841 & 6.06 & 1.32 & 2.97 & 0.335 & 1.54 & 0.209 & 23.6 & 0.71 \\
\hline 17501-1 & Fluorite & ZK17501, $600 \mathrm{~m}$ & 0.386 & 0.723 & 0.175 & 1.52 & 1.40 & 0.593 & 5.26 & 0.946 & 6.95 & 1.56 & 3.65 & 0.380 & 1.84 & 0.210 & 25.6 & 0.67 \\
\hline $17501-6$ & Fluorite & ZK17501, $605 \mathrm{~m}$ & 0.451 & 0.750 & 0.239 & 1.97 & 1.13 & 0.442 & 3.48 & 0.635 & 4.87 & 0.99 & 2.57 & 0.306 & 1.18 & 0.146 & 19.2 & 0.68 \\
\hline 19901 & Fluorite & ZK19901, 675 m & 0.959 & 1.43 & 0.476 & 2.71 & 1.48 & 0.543 & 3.64 & 0.671 & 4.87 & 1.11 & 2.74 & 0.298 & 1.47 & 0.187 & 22.6 & 0.71 \\
\hline 24304-3 & Fluorite & ZK24204, 747 m & 0.559 & 0.768 & 0.226 & 1.38 & 0.815 & 0.340 & 2.20 & 0.365 & 2.62 & 0.62 & 1.43 & 0.166 & 0.714 & 0.099 & 12.3 & 0.78 \\
\hline $23902-34$ & Calcite & ZK23902, 376 m & 0.239 & 0.838 & 0.169 & 1.14 & 0.609 & 0.296 & 1.01 & 0.148 & 0.69 & 0.13 & 0.25 & 0.018 & 0.144 & 0.017 & 5.71 & 1.15 \\
\hline $23902-57$ & Calcite & ZK23902, $441 \mathrm{~m}$ & 0.511 & 2.000 & 0.439 & 3.24 & 2.06 & 0.794 & 2.81 & 0.401 & 2.44 & 0.40 & 0.88 & 0.112 & 0.484 & 0.054 & 16.6 & 1.01 \\
\hline $23902-67$ & Calcite & ZK23902, $487 \mathrm{~m}$ & 0.254 & 0.745 & 0.174 & 1.50 & 2.83 & 1.94 & 7.02 & 1.03 & 5.66 & 0.79 & 1.43 & 0.153 & 0.773 & 0.104 & 24.4 & 1.33 \\
\hline $23902-76$ & Calcite & ZK23902, $522 \mathrm{~m}$ & 0.892 & 1.88 & 0.330 & 1.60 & 0.894 & 0.572 & 1.77 & 0.263 & 1.76 & 0.31 & 0.64 & 0.090 & 0.480 & 0.060 & 11.5 & 1.39 \\
\hline $23908-30$ & Calcite & ZK23908, 427 m & 0.354 & 1.43 & 0.316 & 2.56 & 3.85 & 2.72 & 7.59 & 1.26 & 6.88 & 1.05 & 2.16 & 0.234 & 1.12 & 0.138 & 31.7 & 1.54 \\
\hline
\end{tabular}

Note: $\delta \mathrm{Eu}=\mathrm{Eu}_{\mathrm{N}} / \sqrt{\mathrm{Sm}_{\mathrm{N}} \times \mathrm{Gd}_{\mathrm{N}}}$.

Table 2. Sm and Nd isotope compositions of fluorite and calcite from the Shuiyindong deposit.

\begin{tabular}{|c|c|c|c|c|c|c|c|}
\hline Sample Number & Occurrence & $\mathrm{Sm}(\mu \mathrm{g} / \mathrm{g})$ & $N d(\mu \mathrm{g} / \mathrm{g})$ & $\mathrm{Sm} / \mathrm{Nd}$ & ${ }^{147} \mathrm{Sm} /{ }^{144} \mathrm{Nd}$ & ${ }^{143} \mathrm{Nd} /{ }^{144} \mathrm{Nd}<2 \sigma>$ & $\varepsilon_{\mathrm{Nd}}$ \\
\hline $16701-7$ & $\mathrm{Fl}$ & 1.4365 & 2.3481 & 0.61 & 0.3699 & $0.512637 \pm 0.000006$ & -4.4 \\
\hline $16701-10$ & $\mathrm{Fl}$ & 1.1948 & 1.7974 & 0.66 & 0.4019 & $0.512678 \pm 0.000013$ & -4.4 \\
\hline $17501-1$ & $\mathrm{Fl}+\mathrm{Cal}$ & 1.3179 & 1.2764 & 1.03 & 0.6242 & $0.512981 \pm 0.000023$ & -4.2 \\
\hline $17501-6$ & $\mathrm{Fl}+\mathrm{Cal}$ & 1.2285 & 1.8001 & 0.68 & 0.4126 & $0.512692 \pm 0.000009$ & -4.4 \\
\hline 19901 & $\mathrm{Fl}+\mathrm{Cal}+\mathrm{Qz}$ & 1.6196 & 3.1428 & 0.52 & 0.3115 & $0.512561 \pm 0.000005$ & -4.4 \\
\hline 24304-3 & $\mathrm{Fl}$ & 0.8801 & 1.6124 & 0.55 & 0.3300 & $0.512587 \pm 0.000003$ & -4.4 \\
\hline $23902-34$ & Cal & 0.6734 & 1.1878 & 0.57 & 0.3427 & $0.512721 \pm 0.000010$ & -1.1 \\
\hline 23902-57 & $\mathrm{Cal}+\mathrm{Rlg}+$ Orp & 2.1858 & 3.1230 & 0.70 & 0.4231 & $0.512798 \pm 0.000011$ & -1.2 \\
\hline $23902-67$ & $\mathrm{Cal}+\mathrm{Rlg}+$ Orp & 2.7132 & 1.5875 & 1.71 & 1.0332 & $0.513401 \pm 0.000008$ & -1.1 \\
\hline $23902-76$ & $\mathrm{Cal}+\mathrm{Rlg}+$ Orp & 1.0964 & 1.6630 & 0.66 & 0.3986 & $0.512778 \pm 0.000004$ & -1.1 \\
\hline $23908-30$ & $\mathrm{Cal}+\mathrm{Rlg}+$ Orp & 3.9756 & 2.9210 & 1.36 & 0.8228 & $0.513194 \pm 0.000017$ & -1.1 \\
\hline
\end{tabular}

Abbreviations: Cal—calcite, Rlg—realgar, Orp—orpiment, Fl—fluorite, Qz-quartz. 
The six fluorite samples collected from SBT showed ${ }^{147} \mathrm{Sm} /{ }^{144} \mathrm{Nd}$ and ${ }^{143} \mathrm{Nd} /{ }^{144} \mathrm{Nd}$ values ranging from 0.3115 to 0.6242 and from 0.512561 to 0.512981 , respectively, and yielded a Sm-Nd isochron age of $200.1 \pm 8.6 \mathrm{Ma}$ (Figure 5c), with a low mean square of weighted deviates (MSWD) of 0.47 and an initial ${ }^{143} \mathrm{Nd} /{ }^{144} \mathrm{Nd}$ ratio of $0.512154 \pm 0.000019$ (initial $\varepsilon_{\mathrm{Nd}}(\mathrm{t})=-4.4$ ). The five calcite samples collected from orebodies showed ${ }^{147} \mathrm{Sm} /{ }^{144} \mathrm{Nd}$ and ${ }^{143} \mathrm{Nd} /{ }^{144} \mathrm{Nd}$ values ranging from 0.3427 to 1.0332 and from 0.512721 to 0.513401 , respectively, and yielded a different Sm-Nd isochron age of $150.2 \pm 2.2 \mathrm{Ma}$ (Figure $5 \mathrm{~d}$ ), with a low MSWD of 0.18 and an initial ${ }^{143} \mathrm{Nd} /{ }^{144} \mathrm{Nd}$ ratio of $0.5123854 \pm 0.000081$ (initial $\left.\varepsilon_{N d}(t)=-1.1\right)$. The low MSWD values reflect the excellent fit of the data to a straight line.

\section{Discussion}

The linear relationships shown in Figure $5 c, d$ represent isochrons or mixed lines with two end members having quite different ${ }^{143} \mathrm{Nd} /{ }^{144} \mathrm{Nd}$ and ${ }^{147} \mathrm{Sm} /{ }^{144} \mathrm{Nd}$ ratios. In the former, the slopes of the straight lines determine the ages of fluorite and calcite; in the latter, the slopes have no meaning but simply reflect the isotopic compositions and $\mathrm{Sm} / \mathrm{Nd}$ ratios of the two end members. The variation in $\mathrm{Sm} / \mathrm{Nd}$ ratios is not attributable to the mixing of the two end members because this would result in variable initial $\varepsilon_{N d}(t)$ values. The $\varepsilon_{N d}(t)$ values of fluorite and calcite range from -4.2 to -4.4 and from -1.1 to -1.2 , both showing slight variations. In addition, no linear relationships could be determined from the $1 / \mathrm{Nd}$ vs. ${ }^{143} \mathrm{Nd} /{ }^{144} \mathrm{Nd}$ diagrams for fluorite and calcite (Figure 6 ). Therefore, the possibility of a mixing line can be rejected.
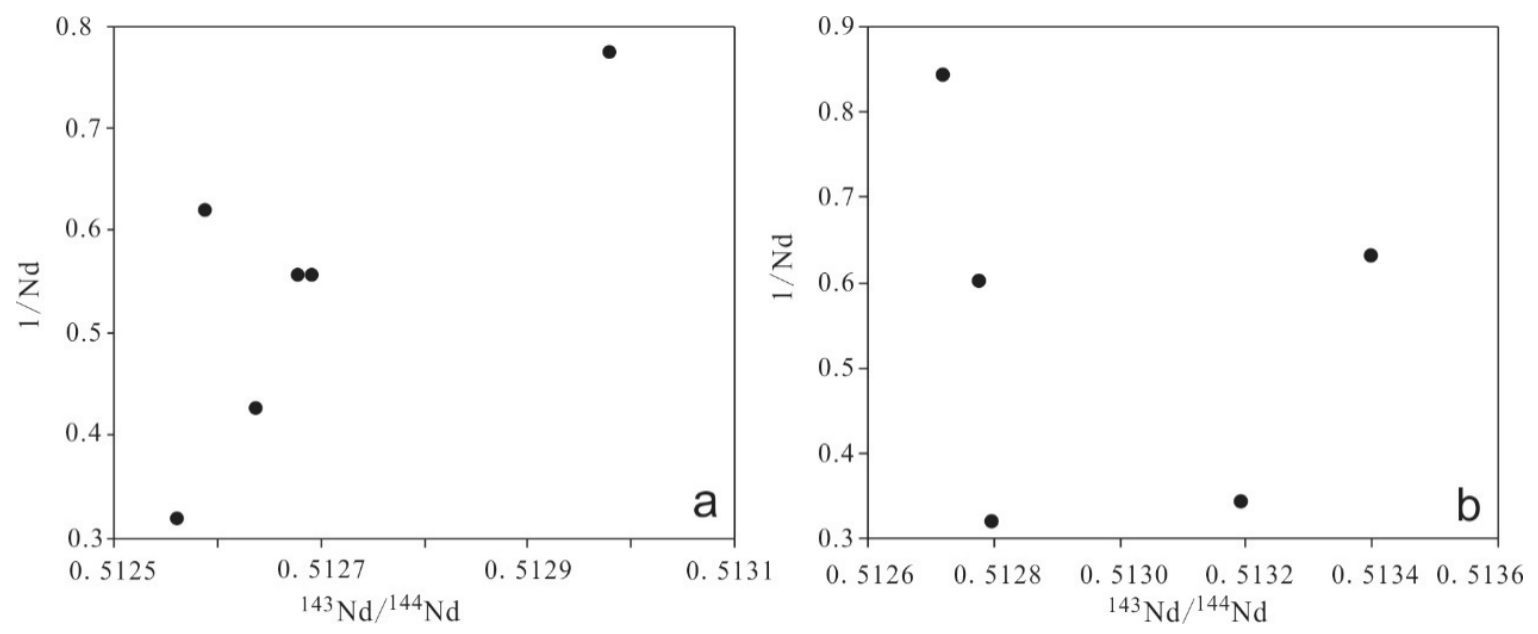

Figure 6. Diagrams of $1 / \mathrm{Nd}$ vs. ${ }^{143} \mathrm{Nd} /{ }^{144} \mathrm{Nd}$ of (a) fluorite and (b) calcite from the Shuiyindong deposit.

The slopes of the straight lines in Figure 5 c,d determine the ages of fluorite $(200.1 \pm 8.6 \mathrm{Ma})$ and calcite $(150.2 \pm 2.2 \mathrm{Ma})$, respectively. The difference in ages suggests the occurrence of two episodes of hydrothermal events at the Shuiyindong deposit. Some important progress has been made for dating hydrothermal minerals from Carlin-type gold deposits in Southwestern China. Some hydrothermal minerals (e.g., calcite and apatite) were deposited during the late Yanshanian Period (ca. 130-150 Ma), based on the Sm-Nd isochron age (calcite; $[10,11]$ ) and the SIMS Th-Pb age (apatite; [12]). However, other hydrothermal minerals (e.g., sericite, arsenopyrite, and rutile) were precipitated during the Indosinian Period (ca. 200-230 Ma), based on the ${ }^{40} \mathrm{Ar}-{ }^{39} \mathrm{Ar}$ plateau age (sericite; [7]), the Re-Os age (arsenopyrite; [8]), and the in situ U-Pb age (rutile; [9]). The two age groups may also imply two distinct low-temperature hydrothermal events in Southwestern China.

To date, there is no consensus on the age of the Shuiyindong gold deposit owing to the lack of minerals clearly related to gold mineralization. The Re-Os isotope age of arsenopyrite (235 $\pm 33 \mathrm{Ma}$; [8]), interpreted as the age of gold mineralization, may be a mixed age. The arsenopyrite is very difficult to separate from pre-ore pyrite, as it is commonly intergrown with zoned pyrite containing pre-ore Au-poor pyrite cores and Au-rich pyrite overgrowth rims (Figure 7a,b; [2,5]). 
Hydrothermal calcite around orebodies is believed to be a product of decarbonatization of the host rocks that served as the main source of Fe for sulfidation during gold deposition [37]. The gold often occurs in invisible forms, including submicroscopic particles, nanoparticles, and crystal lattice gold. Gold submicroscopic particles and nanoparticles are mostly distributed in arsenian pyrite or quartz veinlets, while lattice gold always occurs as crystal lattice in the overgrowth rims of arsenian pyrite $[30,34]$. Decarbonatization and sulfidation are responsible for providing the Fe and $\mathrm{S}$ to form hydrothermal arsenian pyrite, which is the most important mineral coprecipitated with gold. For Carlin-type gold deposits, numerous studies have shown that gold deposition is closely associated with decarbonatization of host strata [28,33,37]. After decarbonatization, host rocks commonly develop high porosity (Figure 7c), and calcite veins fill fractures at the periphery of decarbonated rocks. It is noteworthy that decarbonatization did not occur in the wall rocks, which are nonporous (Figure 7d). Therefore, the age of the calcite $(150.2 \pm 2.2 \mathrm{Ma})$ formed from decarbonatization potentially reflects the age of decarbonatization and gold deposition during the late stages of the Yanshanian Period.
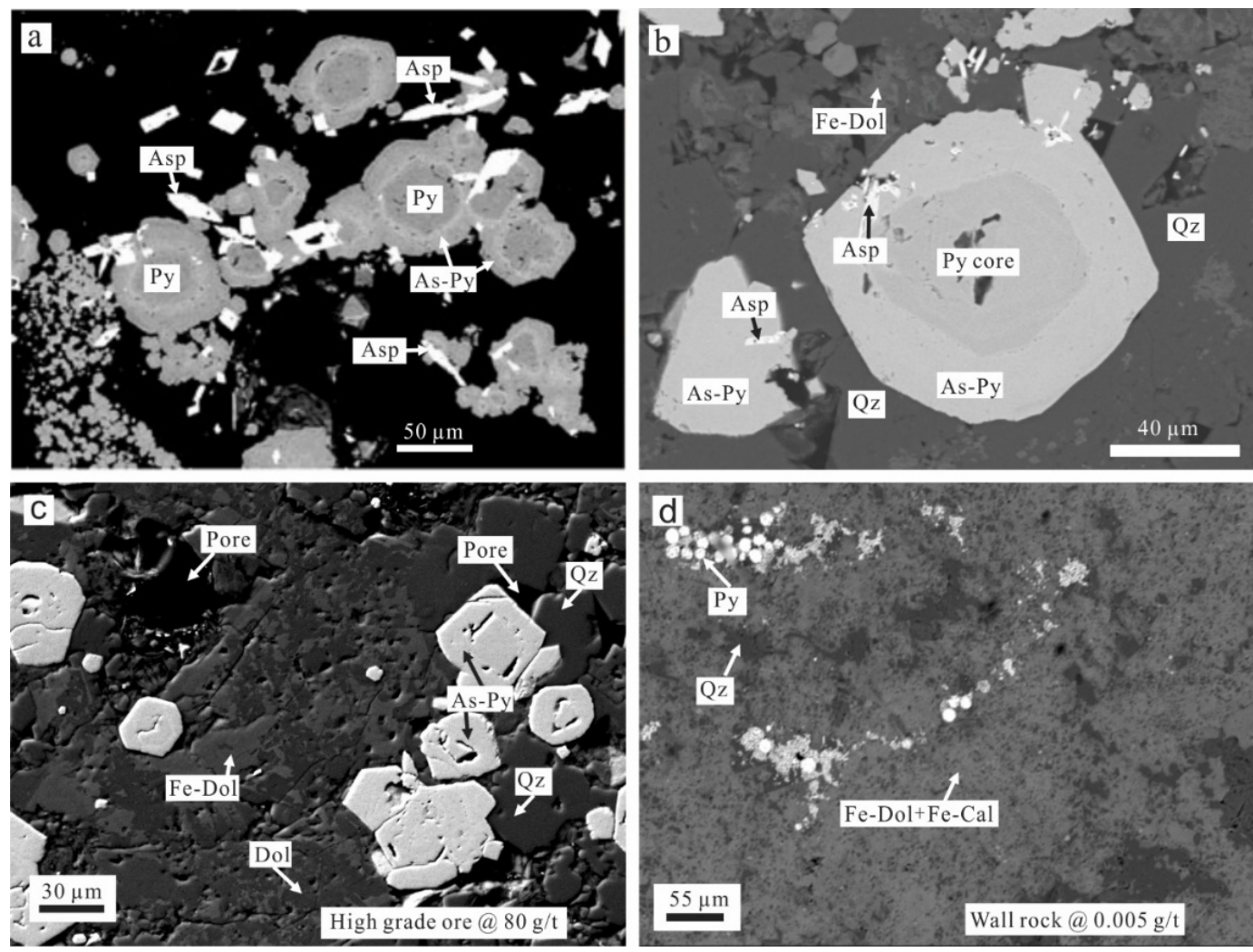

Figure 7. Backscattered electron (BSE) image of selected ore as well as wall rock from Shuiyindong. $(\mathbf{a}, \mathbf{b})$ BSE image of ores containing zoned arsenian pyrite (showing As-rich rims on As-poor pyrite cores) and arsenopyrite (after Su et al. [5,38]). (c) BSE image of high-grade ore showing decarbonatization and high porosity. (d) BSE image of wall rock showing no decarbonatization and nonporous. Abbreviations: Asp—arsenopyrite, As-py—arsenian pyrite, Dol—dolomite, Fe-Cal—ferroan calcite, Fe-Dol—ferroan dolomite, Py-pyrite, Qz-quartz.

Fluorite veins commonly cement argillite breccia or are intergrown with calcite veins at the vicinity of SBT at the Shuiyindong deposit (Figure 4c,d). However, no fluorite appears at decarbonated high-gold-grade rocks or around other types of ores. Until now, the relationship between the precipitation of fluorite and gold mineralization remains uncertain based on geological evidence (e.g., mineral assemblage and paragenetic sequence). The age of the hydrothermal fluorite $(200.1 \pm 8.6 \mathrm{Ma})$ likely records an episode of low-temperature hydrothermal events in the Indosinian Period in Southwestern China. 
Isotope data can also be used to shed some light on the source of the $\mathrm{Nd}$ in the fluorite and calcite. The Maokou formation limestone and Longtan formation shale from the Permian period in Southeastern China have low $\varepsilon_{\mathrm{Nd}}(\mathrm{t})$ values of -6.3 and -12.5 at $150 \mathrm{Ma}$, as calculated using the data of Peng et al. [39] and Chen and Jahn [40], respectively. The basaltic volcanic tuff from the Permian period has an $\varepsilon_{\mathrm{Nd}}(\mathrm{t})$ value of +1.5 , based on the data in Chung and Jahn [41] at $150 \mathrm{Ma}$. The initial $\varepsilon_{\mathrm{Nd}}(\mathrm{t})$ values of fluorite and calcite are -4.4 and -1.1 , respectively, and are in the range of values for Permian limestone (-6.3) and basaltic volcanic tuff $(+1.5)$. This indicates that the $\mathrm{Nd}$ in the fluorite and calcite probably originated from mixtures of basaltic volcanic tuff and bioclastic limestone of the Permian formations, such as the Longtan formation.

\section{Conclusions}

Fluorite and calcite from the Shuiyindong gold deposit contain considerable concentrations of $\mathrm{REE}$, and exhibit variable $\mathrm{Sm} / \mathrm{Nd}$ ratios, facilitating the direct dating of associated hydrothermal events. The fluorite and calcite yielded Sm-Nd isochron ages of $200.1 \pm 8.6\left(\right.$ initial $\varepsilon_{\mathrm{Nd}}(\mathrm{t})=-4.4 ;$ MSWD $=0.47$ ) and 150.2 $\pm 2.2 \mathrm{Ma}$ (initial $\varepsilon_{\mathrm{Nd}}(\mathrm{t})=-1.1 ; \mathrm{MSWD}=0.18$ ), respectively. These two groups of $\mathrm{Sm}-\mathrm{Nd}$ isochron ages suggest two episodes of hydrothermal events in Shuiyindong. The age of the calcite probably represents the late stage of the gold mineralization period. Initial Nd isotopic compositions indicate that the $\mathrm{Nd}$ in the fluorite and calcite was likely derived from mixtures of basaltic volcanic tuff and bioclastic limestone of the Permian formations.

Author Contributions: Y.X. designed the study concept and revised the manuscript; Q.T. contributed to the analysis, data interpretation and manuscript preparation; Q.T., Z.X., Z.W., and D.W. collected the calcite and fluorite samples; Y.Z., J.Y., and S.L. drawn the geologic maps.

Funding: This work was financially supported by the National Key R\&D Program of Deep penetrating Geochemistry (2016YFC0600607) and the National Natural Science Foundation of China (41803046).

Acknowledgments: We wish to thank the geological workers from the Guizhou Bureau of Geology and Mineral Resource Guizhou and the Guizhou Zijin Gold Mines for their help during our field investigation.

Conflicts of Interest: The authors declare no conflict of interest.

\section{References}

1. Yan, J.; Hu, R.Z.; Liu, S.; Lin, Y.T.; Zhang, J.C.; Fu, S.L. NanoSIMS element mapping and sulfur isotope analysis of Au-bearing pyrite from Lannigou Carlin-type Au deposit in SW China: New insights into the origin and evolution of Au-bearing fluids. Ore Geol. Rev. 2018, 92, 29-41. [CrossRef]

2. Xie, Z.J.; Xia, Y.; Cline, J.S.; Koenig, A.; Wei, D.T.; Tan, Q.P.; Wang, Z.P. Are There Carlin-Type Gold Deposits in China? A Comparison of the Guizhou, China, Deposits with Nevada, USA, Deposits. In Diversity of Carlin-Style Gold Deposits, Reviews in Economic Geology; Muntean, J.L., Ed.; Society of Economic Geologists: Littleton, CO, USA, 2018; Volume 20, pp. 187-233.

3. Hu, R.Z.; Fu, S.L.; Huang, Y.; Zhou, M.F.; Fu, S.H.; Zhao, C.H.; Wang, Y.J.; Bi, X.W.; Xiao, J.F. The giant South China Mesozoic low-temperature metallogenic domain: Reviews and a new geodynamic model. J. Asian Earth Sci. 2017, 137, 9-34. [CrossRef]

4. Xie, Z.J.; Xia, Y.; Cline, J.S.; Pribil, M.J.; Koenig, A.; Tan, Q.P.; Wei, D.T.; Wang, Z.P.; Yan, J. Magmatic Origin for Sediment-Hosted Au Deposits, Guizhou Province, China: In Situ Chemistry and Sulfur Isotope Composition of Pyrites, Shuiyindong and Jinfeng Deposits. Econ. Geol. 2018, 113, 1627-1652.

5. Su, W.C.; Dong, W.D.; Zhang, X.C.; Shen, N.P.; Hu, R.Z.; Hofstra, A.H.; Cheng, L.Z.; Xia, Y.; Yang, K.Y. Carlin-Type Gold Deposits in the Dian-Qian-Gui "Golden Triangle" of Southwest China. In Diversity of Carlin-Style Gold Deposits, Reviews in Economic Geology; Muntean, J.L., Ed.; Society of Economic Geologists: Littleton, CO, USA, 2018; Volume 20, pp. 157-185.

6. 1:2,500,000 Chinese Geological Map, The National Geological Archives of China. Available online: http://geodata.ngac.cn/Document/Map.aspx?MapId=EC7E1A7A7CF81954E0430100007F182E (accessed on 12 April 2019). 
7. Chen, M.H.; Huang, Q.W.; Hu, Y.; Chen, Z.Y.; Zhang, W. Genetic type of Phyllosilicate (Micas) and its Ar-Ar dating in Lannigou gold deposit, Guizhou Province, China. Acta Mineral. Sin. 2009, 29, 353-362. (In Chinese with English Abstract)

8. Chen, M.H.; Mao, J.W.; Li, C.; Zhang, Z.Q.; Dang, Y. Re-Os isochron ages for arsenopyrite from Carlin-like gold deposits in the Yunnan-Guizhou-Guangxi "golden triangle", southwestern China. Ore Geol. Rev. 2015, 64, 316-327.

9. Pi, Q.H.; Hu, R.Z.; Xiong, B.; Li, Q.L.; Zhong, R. In situ SIMS U-Pb dating of hydrothermal rutile: Reliable age for the Zhesang Carlin-type gold deposit in the golden triangle region, SW China. Miner. Depos. 2017, 52, 1179-1190. [CrossRef]

10. Su, W.C.; Hu, R.Z.; Xia, B.; Xia, Y.; Liu, Y.P. Calcite Sm-Nd isochron age of the Shuiyindong Carlin-type gold deposit, Guizhou, China. Chem. Geol. 2009, 258, 269-274. [CrossRef]

11. Wang, Z.P. Genesis and Dynamic Mechanism of the Epithermal Ore Deposits, SW Guizhou, China-A Case Study of Gold and Antimony Deposits. Ph.D. Thesis, University of Chinese Academy of Sciences, Beijing, China, 2013. (In Chinese with English Abstract)

12. Chen, M.H.; Bagas, L.; Liao, X.; Zhang, Z.Q.; Li, Q.L. Hydrothermal apatite SIMS ThPb dating: Constraints on the timing of low-temperature hydrothermal Au deposits in Nibao, SW China. Lithos 2019, 324-325, 418-428.

13. Peng, J.T.; Hu, R.Z.; Burnard, P.G. Samarium-neodymium isotope systematics of hydrothermal calcites from the Xikuangshan antimony deposit (Hunan, China): The potential of calcite as a geochronometer. Chem. Geol. 2003, 200, 129-136. [CrossRef]

14. Jiang, S.Y.; Slack, J.F.; Palmer, M.R. Sm-Nd dating of the giant Sullivan Pb-Zn-Ag deposit, British Columbia. Geology 2000, 28, 751-754.

15. Anglin, C.D.; Jonasson, I.R.; Franklin, J.M. Sm-Nd dating of scheelite and tourmaline; implications for the genesis of Archean gold deposits, Val d'Or, Canada. Econ. Geol. 1996, 91, 1372-1382. [CrossRef]

16. Chesley, J.T.; Halliday, A.N.; Kyser, T.K.; Spry, P.G. Direct dating of mississippi valley-type mineralization; use of Sm-Nd in fluorite. Econ. Geol. 1994, 89, 1192-1199. [CrossRef]

17. Chesley, J.T.; Halliday, A.N.; Scrivener, R.C. Samarium-neodymium direct dating of fluorite mineralization. Science 1991, 252, 949-951. [CrossRef] [PubMed]

18. Zou, Z.C.; Hu, R.Z.; Bi, X.W.; Wu, L.Y.; Feng, C.X.; Tang, Y.Y. Absolute and relative dating of Cu and Pb-Zn mineralization in the Baiyangping area, Yunnan Province, SW China: Sm-Nd geochronology of calcite. Geochem. J. 2015, 49, 103-112. [CrossRef]

19. Wang, J.S.; Wen, H.J.; Fan, H.F.; Zhu, J.J. Sm-Nd geochronology, REE geochemistry and C and O isotope characteristics of calcites and stibnites from the Banian antimony deposit, Guizhou Province, China. Geochem. J. 2012, 46, 393-407. [CrossRef]

20. Uysal, I.T.; Zhao, J.X.; Golding, S.D.; Lawrence, M.G.; Glikson, M.; Collerson, K.D. Sm-Nd dating and rare-earth element tracing of calcite: Implications for fluid-flow events in the Bowen Basin, Australia. Chem. Geol. 2007, 238, 63-71. [CrossRef]

21. Roberts, S.; Palmer, M.R.; Waller, L. Sm-Nd and REE characteristics of tourmaline and scheelite from the Bjorkdal gold deposit, northern Sweden: Evidence of an intrusion-related gold deposit? Econ. Geol. 2006, 101, 1415-1425. [CrossRef]

22. Bell, K.; Anglin, C.; Franklin, J. Sm-Nd and Rb-Sr isotope systematics of scheelites: Possible implications for the age and genesis of vein-hosted gold deposits. Geology 1989, 17, 500-504. [CrossRef]

23. Chernyshev, I.V.; Golubev, V.N.; Aleshin, A.P.; Larionova, Y.O.; Gol'tsman, Y.V. Fluorite as an Sm-Nd geochronometer of hydrothermal processes: Dating of mineralization hosted in the Strel'tsovka uranium ore field, eastern Baikal region. Geol. Ore Depos. 2016, 58, 447-455. [CrossRef]

24. Xu, W.G.; Fan, H.R.; Hu, F.F.; Santosh, M.; Yang, K.F.; Lan, T.G.; Wen, B.J. Geochronology of the Guilaizhuang gold deposit, Luxi Block, eastern North China Craton: Constraints from zircon U-Pb and fluorite-calcite Sm-Nd dating. Ore Geol. Rev. 2015, 65, 390-399. [CrossRef]

25. Munoz, M.; Premo, W.; Courjault-Rade, P. Sm-Nd dating of fluorite from the worldclass Montroc fluorite deposit, southern Massif Central, France. Miner. Depos. 2005, 39, 970-975. [CrossRef]

26. Tan, Q.P.; Xia, Y.; Wang, X.Q.; Xie, Z.J.; Wei, D.T. Carbon-oxygen isotopes and rare earth elements as an exploration vector for Carlin-type gold deposits: A case study of the Shuiyindong gold deposit, Guizhou Province, SW China. J. Asian Earth Sci. 2017, 148, 1-12. [CrossRef] 
27. Liu, J.Z.; Yang, C.F.; Wang, Z.P.; Wang, D.F.; Qi, L.S.; Li, J.H.; Hu, C.W.; Xu, L.Y. Geological research of Shuiyindong gold deposit in Zhenfeng County, Guizhou Province. Geol. Surv. China 2017, 4, 32-41. (In Chinese with English Abstract)

28. Tan, Q.P.; Xia, Y.; Xie, Z.J.; Yan, J. Migration paths and precipitation mechanisms of ore-forming fluids at the Shuiyindong Carlin-type gold deposit, Guizhou, China. Ore Geol. Rev. 2015, 69, 140-156. [CrossRef]

29. Zhu, J.J.; Hu, R.Z.; Richards, J.P.; Bi, X.-W.; Stern, R.; Lu, G. No genetic link between Late Cretaceous felsic dikes and Carlin-type Au deposits in the Youjiang basin, Southwest China. Ore Geol. Rev. 2017, 84, 328-337. [CrossRef]

30. Su, W.C.; Xia, B.; Zhang, H.T.; Zhang, X.C.; Hu, R.Z. Visible gold in arsenian pyrite at the Shuiyindong Carlin-type gold deposit, Guizhou, China: Implications for the environment and processes of ore formation. Ore Geol. Rev. 2008, 33, 667-679. [CrossRef]

31. Tan, Q.P.; Xia, Y.; Xie, Z.J.; Yan, J.; Wei, D.T. S, C, O, H, and Pb isotopic studies for the Shuiyindong Carlin-type gold deposit, Southwest Guizhou, China: Constraints for ore genesis. Chin. J. Geochem. 2015, 34, 525-539. [CrossRef]

32. Tan, Q.P.; Xia, Y.; Wang, X.Q.; Xie, Z.J.; Wei, D.T. Tectonic model and tectonic-geochemistry characteristics of the Huijiabao gold orefield, SW Guizhou Province. Geotecton. Metallog. 2017, 41, 291-304. (In Chinese with English Abstract)

33. Cline, J.S. Nevada's Carlin-Type Gold Deposits: What We' ve Learned During the Past 10 to 15 Years. In Diversity of Carlin-Style Gold Deposits, Reviews in Economic Geology; Muntean, J.L., Ed.; Society of Economic Geologists: Littleton, CO, USA, 2018; Volume 20, pp. 7-37.

34. Li, X.X.; Zhu, X.Q.; Gu, Y.T.; Ling, K.Y.; Sheng, X.Y.; He, L. Mineralogy and Geochemistry Characteristics and Genetic Implications for Stratabound Carlin-Type Gold Deposits in Southwest Guizhou, China. J. Nanosci. Nanotechnol. 2017, 17, 6307-6317. [CrossRef]

35. Zhang, J.R.; Wen, H.J.; Qiu, Y.Z.; Zhang, Y.X.; Li, C. Ages of sediment-hosted Himalayan Pb-Zn-Cu-Ag polymetallic deposits in the Lanping basin, China: Re-Os geochronology of molybdenite and Sm-Nd dating of calcite. J. Asian Earth Sci. 2013, 73, 284-295. [CrossRef]

36. Ludwig, R.K. ISOPLOT: A plotting and regression program for radiogenic isotope data (Version 2.9). U.S. Geol. Surv. Open-File Rep. 1996, 91, 445-447.

37. Su, W.C.; Heinrich, C.A.; Pettke, T.; Zhang, X.C.; Hu, R.Z.; Xia, B. Sediment-hosted gold deposits in Guizhou, China: Products of wall-rock sulfidation by deep crustal fluids. Econ. Geol. 2009, 104, 73-93. [CrossRef]

38. Su, W.C.; Zhang, H.T.; Hu, R.Z.; Ge, X.; Xia, B.; Chen, Y.Y.; Zhu, C. Mineralogy and geochemistry of gold-bearing arsenian pyrite from the Shuiyindong Carlin-type gold deposit, Guizhou, China: Implications for gold depositional processes. Miner. Depos. 2012, 47, 653-662. [CrossRef]

39. Peng, J.T.; Hu, R.Z.; Jiang, G.H. Samarium-Neodymium isotope system of fluorites from the Qinglong antimony deposit, Guizhou Province: Constrains on the mineralizing age and ore-forming materials' sources. Acta Petrol. Sin. 2003, 19, 785-791. (In Chinese with English Abstract)

40. Chen, J.F.; Jahn, B.M. Crustal evolution of southeastern China: Nd and Sr isotopic evidence. Tectonophysics 1998, 284, 101-133. [CrossRef]

41. Chung, S.-L.; Jahn, B.-M. Plume-lithosphere interaction in generation of the Emeishan flood basalts at the Permian-Triassic boundary. Geology 1995, 23, 889-892. [CrossRef]

(C) 2019 by the authors. Licensee MDPI, Basel, Switzerland. This article is an open access article distributed under the terms and conditions of the Creative Commons Attribution (CC BY) license (http://creativecommons.org/licenses/by/4.0/). 